質問紙法による小学生の身体活動評価の有用性

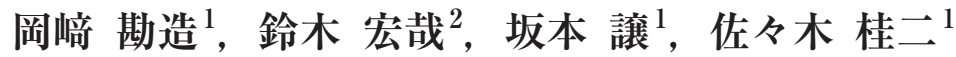

\title{
Usefulness of a self-reported physical activity questionnaire assessment for Japanese children
}

\author{
Kanzo Okazaki $^{1}$, Koya Suzuki ${ }^{2}$, Yuzuru Sakamoto ${ }^{1}$ and Keiji Sasaki ${ }^{1}$ \\ ${ }^{1}$ 東北学院大学教養学部, =981-3193 宮城県仙台市泉区天神沢2-1-1 (Faculty of Liberal Arts, Tohoku Gakuin University, \\ 2-1-1 Tenjinzawa, Izumi-ku, Sendai, Miyagi 981-3193, Japan) \\ 2 順天堂大学スポーツ健康科学部, テ270-1695 千葉県印西市平賀学園台1-1 (Faculty of Health and Sports Science, Jun- \\ tendo University, 1-1 Hiraka-gakuendai, Inzai-city, Chiba 270-1695, Japan)
}

Received: March 22, 2017 / Accepted: September 7, 2017

\begin{abstract}
The study aimed to assess a self-reported questionnaire about physical activity (PA) from the Health Behaviour in School-aged Children (HBSC) using triaxial accelerometer as a criterion. Elementary school boys $(\mathrm{N}=292)$ and girls $(\mathrm{N}=313)$ in the fourth grade and higher completed the questionnaire and wore an accelerometer for at least $10 \mathrm{~h} /$ day for at least 4 days. The phi coefficients of the chi-square test 2-way tables (active/inactive as measured using the HBSC questionnaire $\times$ achievement/non-achievement of the recommended 60 -min moderate to vigorous $\mathrm{PA}[\mathrm{MVPA}]$ as measured using the accelerometer) were $0.25(\mathrm{P}<0.001), 0.17(\mathrm{P}=0.009)$, and $0.08(\mathrm{P}=0.217)$ for all children, boys, and girls, respectively. The sensitivity and specificity in boys were $82 \%(95 \%$ confidence interval $[\mathrm{CI}]=78-86 \%)$ and $34 \%(95 \% \mathrm{CI}=26-41 \%)$ respectively, while the those of girls were $52 \%(95 \% \mathrm{CI}=40-63 \%), 57 \%(95 \% \mathrm{CI}=55-60 \%)$. The positive predictive value in boys was $70 \%(95 \% \mathrm{CI}=66-73 \%)$ and negative predictive value in girls was $83 \%(95 \% \mathrm{CI}=79-87 \%)$. The independent t-test showed that moderate PA (MPA), vigorous PA (VPA), and MVPA min/day of active children were significantly higher than those of inactive children (range of Cohen's d=0.38 to 0.71). Area under the curve (AUC) of the VPA (AUC = $0.60-0.73$ ) in girls was significantly higher than that of the MPA (AUC $=0.52-0.65$ ) and MVPA $(\mathrm{AUC}=0.54-0.67)$. Our results supported that the HBSC self-reported questionnaire has acceptable, but limited agreement for assessing achievement/non-achievement of the MVPA recommendation, and could estimate the differences in the MPA, VPA, and MVPA min/day of children.
\end{abstract}

Jpn J Phys Fitness Sports Med, 66(6): 407-416 (2017)

Keywords : physical activity, accelerometer, self-reported questionnaire, elementary school, Health Behaviour in School-aged Children survey

\begin{abstract}
緒言
活動的な日常生活が, 学齢期の子どもの健康に恩恵を もたらすことが報告されており，例えば，身体活動によ る体力の向上, 体脂肪の減少, 肥満予防, 骨密度の増加, 抑うつ症状の減少に対する効果が期待できる ${ }^{1-3)}$ 。これ ら効果への期待から, 世界保健機関4) の Global recommendations on physical activityでは，5歳から 17 歳を 対象に，少なくとも 3 METs（metabolic equivalents） 強度以上の身体活動 (moderate-to-vigorous physical activity; MVPA) を，1日あたり60分以上行うことを推 奨している。我が国の子どもにおいても，1日あたり 60

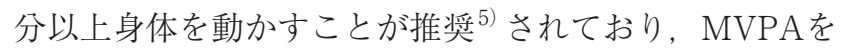

少なくとも毎日60分間以上行う基準は, 子どもの健やか な成長にとって重要な視点の一つである.

子どもを含むヒトの身体活動時間を推定する一つの ツールとして, 活動量計が利用されている. 活動量計は, 日内変動, 日間変動など身体活動パターンや, 強度別に 身体活動時間を推定できる ${ }^{6)}$.この活動量計を用いれば, 我が国の子どもが，上述したMVPAのガイドライン ${ }^{4,5)}$ に対し，充足，あるいは非充足など，身体活動時間につ いて精度の高い推定と判別が可能となった．近年の活動 量計の進歩は著しく, 小学生においても, 成人と同様に, 強度別に身体活動を推定 ${ }^{7)}$ し，ガイドラインに対する充 足の有無を評価できるようになった。

活動量計以外に，子どもの身体活動を推定する方法と 
して, 例えば, 質問紙法がある。質問紙法は, 安価で企画・ 実行しやすく, 短時間で実施が可能である ${ }^{8,9)}$ ため, 学校 現場など研究機関でなくとも, 手軽に導入し, 評価に用 いることもできる。したがって, 質問紙法によって推定 された子どもの活動と, 近年, 注目されている活動量計 との関連を検討し，その関連の程度を明らかにすること は，身体活動を推定する手段の選択肢に，有益な情報と なり得る。

日本の子どもを対象とし, 活動量計と質問紙法の関 連に関する先行研究について, 最近では, 児童を対象 としたOkuda et al. ${ }^{10)}$ の横断研究がみられる. Okuda et al. ${ }^{10)}$ の研究では, 小学 5 年生を対象とし, 活動量計 によるMVPA 時間（分）の評価を基準に, 質問紙法の MVPA 時間（分）との関連を検討していた，質問紙に よる調査項目は, 国民健康・栄養調査を参考に作成され, 男子 $(\mathrm{N}=21)$ の相関は $\mathrm{r}=0.404(\mathrm{P}=0.078)$, 女子 $(\mathrm{N}=26)$ はr=0.312（P=0.14）であり,いずれにおいても MVPA 時間に有意な相関関係はみられず，小学生の活動量計と 質問紙法との妥当性に課題が残されていた。 Okuda et al. ${ }^{10)}$ 以前の報告では, Chen et al. ${ }^{11)}$ が, 日本の小学生 4 年生から 6 年生の児童を対象とし, 活動量計と質問紙法 との関連を検討していた，質問紙の調査項目は，独自の 4 項目が設問されており，1つ目が「放課後スポーツク ラブに通っているか（2 件法)」，2つ目が，身体活動ま たは外遊びの「頻度 ( 3 件法)」, 3 つ目が「強度 ( 3 件法)」, 4 つ目が「好み（ 3 件法）」であった。いずれの調查項 目においても，活動量計から算出された 1 日あたりの活 動量 (kcal), 歩数 (steps) に扔いて, 回答者の群間に 有意差がみられ，すなわち，活動量，歩数に違いがある ことが報告されていた。 ただし，このChen et al. ${ }^{11)}$ の研 究では, MVPA時間との関連は検討されていない.

国外では, Chinapaw et al. ${ }^{12)}$ が, 子どもを対象とし, 活動量計と質問紙法との関連についてまとめている。 小 学生を対象に質問紙法の特性を検討した研究では，25編 がレビューされ，そのうち19編が活動量計との関連を比 較していた。ただし，この中には，紙媒体による調査だ けでなく, 質問文への理解を促進させるため, コンピュー 夕画像を提供する方法も含まれている。19編の論文に おける関連の度合いについては，いずれの質問紙による 評価に扔いても，十分とは言い難く，質問紙法による身 体活動の推定について課題が残されていた１9編の論 文に扔いて, 一部, 低学年児童を対象とし, 親や教員が 回答する子どもの身体活動の評価 $(r=0.53)^{13)}$, および, ビデオを見ながら览童が回答する方法 $(r=0.40)^{14)}$ は, 比較的高い相関がみられたとレビュー研究 ${ }^{12)}$ で報告さ れていたが，両者とも，1990年代後半頃に実施，ある いは公表された論文であり, 垂直 1 軸方向の活動量計 (caltrac accelerometer) ${ }^{15)}$ から算出されたMVPA時間を
基準としているため, 近年の活動量計とは異なる。活動 量計の性能のうち, 例えば, エポック長は, 短時間に設 定できるなどの性能が進歩しており, 現在の活動量計と は，結果が異なる可能性が指摘 ${ }^{12)}$ されていた。

身体活動の質問紙法の一つとして, Health Behaviour in School-aged Children (HBSC) study (http://www. hbsc.org/publications/international/）の身体活動に関 する項目がある。身体活動に関する質問項目 ${ }^{16)}$ は，頻 度と時間の 2 項目で構成され，頻度と時間それぞれの択 一式回答から「active」「inadequately active」など $2 つ$ に分類される。 上記URLのHBSC の説明部分（About HBSC）では，この質問紙による評価方法は，世界保健 機関でも導入されており, 現在, 欧米45か国の調查に利 用されていることが記載されている. HBSC studyの調 查自体は，1982年から欧州を中心に，学齢期の子どもの 健康行動を調査するために始まったものであり，身体活 動以外の調查項目も含まれる。この質問紙法の身体活動 に関する項目の精度は, 高倉ら ${ }^{17)} に よ り 日$ 本人小学生を 対象に検証がなされ，体力テストとの関連，および再現 性が確認されている。しかしながら，HBSCの質問紙法 と活動量計との関連性を検討した研究はみあたらない. HBSC の質問紙法と活動量計との身体活動評価に関連が みられれば, MVPAのガイドラインを基準とした子ども の身体活動状況の推測や，その他健康関連項目との関連 性を検討できるッールとして役立つ.さらに, HBSCは, 国外で利用されており，国外との比較から，我が国の小 学生の現状を推察することにも貢献できる.

以上より, 本研究では, 活動量計による身体活動を基 準とし，HBSCの質問紙法によって評価された身体活 動との関連を検討することを目的とした，具体的には， HBSCの質問紙法で分類された 2 群 (active, inactive) と, 活動量計によるMVPA ガイドライン ${ }^{4,5}$ 充足・非充足に よる 2 群が一致するか，HBSCの質問紙法で分類された 2 群間の活動量計による身体活動時間に差があるか，さ らには，その分類されたactive, inactiveの 2 群がどの 強度の身体活動で予測されているかを検討した，活動 量計による身体活動は, 中等度強度 (3 METs 以上 6.0 METs未満, moderate physical activity; MPA), 高強度 (6 METs以上, vigorous physical activity; VPA)，およ びMVPAに分類し検討した.

\section{方法}

調査対象および手順 調查対象者は, 2011年から 2014年 までの調查に参加した宮城県内の小学校 3 校いずれかに 通う 4 年生以上の児童 760 名とした。調查票には644名 （85\%）が回答し, 活動量のデー夕は732名 (96\%) から 得ることができた，分析対象は，自記式による質問調査 票に回答し，かつ活動量計の分析基準を満たした606名 
（80\%）とした，調査は，東北学院大学倫理委員会による 承認（2011.R001）を受けており，児童には調査の説明を 行い，保護者には書面で説明を行うとともに同意を得て 調査を行った。調査は, 教育委員会, 学校, 保護者の協 力の下に行われた。

児童への調査説明について, 児童は学校内の一堂に集 合し，著者らが放課後などに説明した，児童には，資料 を配付し, 調查全体の概要, および活動量計の注意事項 (装着期間, 回収日, 睡眠, お風呂・水泳などの水と関わる 活動時には外すこと, 着替え後の装着忘れ, 洗濯時の外 し忘れなど）を説明した，説明後に，著者らが，活動量 計を各児童に配布し，その場で装着するようにした。自 記式による質問紙調查票は, 活動量計の装着と同時期に, 担任教諭から児童に配布・回収するよう依頼した，児童 は, 調査票を自宅に持ち帰り回答し, 後日学校に持参し, 担任教諭が学校で回収した。

\section{調査項目}

基本属性として, 性, 学年, 身長, 体重を, 自記式によ る質問紙調査法によって評価した。肥満度は, 調査票の 身長, 体重を用いて算出した. 肥満度を算出するに際して, 標準体重は, 先行研究 ${ }^{18)}$ を参考に, 男女, 年齢, 身長別 に算出した，肥満度は，20\%以上を肥満と分類した ${ }^{19)}$.

質問紙法による身体活動 質問紙法による活動状況は, HBSC studyの先行研究 ${ }^{16,17)}$ を参考に調查項目を作成し た. HBSC studyの調査項目は, 頻度と時間の 2 項目で 構成されている。頻度の質問文は，「あなたは，ふだん， 授業以外で息切れしたり汗をかいたりするくらいの運 動・スポーツ活動を何回しますか」とし，「毎日」,「週に $4 \sim 6$ 回」,「週に $2 \sim 3$ 回」,「週に 1 回」,「月に 1 回」,「月 に 1 回未満」,「まったくしない」の 7 項目で評定した. 一方，時間は「あなたは，ふだん，授業以外で息切れし たり汗をかいたりするくらいの運動・スポーツ活動を 1 週間に何時間しますか」とし，「ぜんぜんしない」，「週 に約 30 分」,「週に約 1 時間」,「週に約 $2 \sim 3$ 時間」,「週 に約 $4 \sim 6$ 時間」,「週に 7 時間以上」の 6 項目で評定した。

対象者は, これら頻度と時間の 2 項目から active と inactiveに分類され，すなわち，頻度が「週に2 2 回」 以上，かつ時間が「週に約 1 時間」以上と回答した児童 はactiveとし，それ以外の「週に1回」以下，または「週 に約30分」以下と回答した児童は inactive と分類した。 この分類は, 先行研究 ${ }^{16,17)}$ に準じて分類した.

HBSC studyの日本語版における信頼性, 妥当性は, 高倉ら ${ }^{17)}$ の研究によって報告されており, 信頼性では, 評定一致割合が $87 \%$ から $98 \%$ を示し, 妥当性では, 体力 テストとの関連が検討され, activeに分類された児童は, inactive と分類された児童に比べ, 体力テストの総合得
点，持久力が高いと報告されている.

活動量計による身体活動 活動量計は, オムロン・ヘル スケア社の活動量計 Active style Pro（HJA350IT）を用 いた.この活動量計は, 測定軸が 3 軸あり, 歩・走行活動, および生活活動による強度別の活動時間を算出できる ${ }^{6)}$. 精度は, ヒトの活動を推定できる機器として既に確認さ れて扔り ${ }^{20-22)}$ ，小学生の身体活動に打いても強度別に推 定が可能である ${ }^{7)}$. 本研究においても, Hikihara ( $^{7)}$ を 参考に, 活動量計の值を子どもに推定した. 具体的には, 活動量計で推定できる歩行活動とそれ以外の活動につ いて, 歩行活動は, $0.6237 \times$ 活動量計による METs 評価 +0.2411 とし, 歩行以外の活動は, $0.6415 \times$ 活動量計に よるMETs評価+0.5573とし推定した。

活動量計の装着, エポック長は, Cain et al. ${ }^{23)}$ を参考 に以下のように設定した：活動量計の装着部位は, 腰 部とし，装着期間は休日 2 日間を含む 7 日間以上とし た。活動量計の腰部への装着側は, 左右いずれか装着し やすい方に装着するよう指示した，実際に装着してい たかは, 本研究では, 10 分以上連続して計測なしの場 合，装着していない時間とみなし，装着時間が，1日あ たり 600 分以上みられた日のデータを装着ありとみなし た。この装着ありとみなされた日数が，平日 3 日間以 上，かつ休日 1 日間以上みられた対象者のデー夕を採用 し，平均的な 1 週間の 1 日あたり MPA，VPAの各時間 を算出した，各時間の算出は，平日採用日数の時間の和 と休日採用日数の和を加え, 平日・休日の採用日数で除 した，MVPA時間は, MPA とVPAの各時間の和とし, MVPA 時間が，1 日あたり 60 分以上の児童を, 先行研 究 ${ }^{4,5)}$ に準じてガイドライン充足とした。児童の装着状 況について，紙媒体などによる記録はしていない，活動 量計のエポック長は 10 秒間に設定し, 10秒単位で評価さ れた活動強度（METs）から，MPA，VPAの各活動時間 を算出した．エポック長は，60秒間に設定されることが 多いが, 近年, 子どもの複雑な動きに対しては, エポック 長を10秒間に設定されることが推奨されている, ${ }^{9,12)}$. 活 動量計のデー夕処理について, 回収された活動量計のデー タをパソコンにダウンロードし, エクセルで処理した.

分析方法 統計解析には, SPSS 22.0J for windows, お よびBellCurve for Excel 2.02を用いて分析した. 統計学 的有意水準は, 全て $5 \%$ 未満とした。

身体活動状況の性差が報告 ${ }^{24-26)}$ されているため, 本研 究に扔いても，身体活動の男女差を確認後分析した，男 女差の分析について, 体型に関する肥満度, HBSCの質 問紙法による活動状況 (active, inactive), および活動 量計によるガイドライン充足の有無に対する分布割合 は， $\chi^{2}$ 検定を用いて分析し，1日あたりのMPA，VPA， 
MVPAの各時間における男女差は, 各平均時間を対応の ない $\mathrm{t}$ 検定で分析した.

HBSCの質問紙法によって分類された 2 群間（active, inactive）におけるMPA, VPA, MVPAの各時間の差を 検討するため，対応のない $\mathrm{t}$ 検定を用いて分析した。

対応のない $\mathrm{t}$ 検定において，等分散性が棄却された場 合には, Welchの検定を用いた。

HBSCの質問紙法で分類された 2 群 (active, inactive) と, 活動量計で分類された 2 群（ガイドライン充足, 非 充足）との一致の度合いを検討するため, 活動量計を基 準とし, 質問紙による分類の感度, 特異度, 陽性的中率, 陰性的中率, および一致率の $\phi$ 係数を算出した，感度は， ガイドラインを充足している児童のうち，質問紙の評価 に抢いても充足と判別される割合を示し, 特異度は, ガ イドライン非充足の児童のうち, 質問紙の評価に拀いて も非充足と判別される割合を示す。陽性的中率は，質問 紙でガイドライン充足と判別された児童が，実際にガイ ドラインを充足している確率を示し，陰性的中率は，質 問紙でガイドライン非充足と判別された児童が，実際に 非充足と判別される確率を示す。これら感度, 特異度と 同じく，実際の学術調查等で利用する場合には，実際に 基準に対する充足，非充足かどうかが関心ごとになるこ ともあり，陽性抢よび陰性的中率の高さも示した ${ }^{27)}$.

ROC (receiver operating characteristic) 曲線の AUC (area under the curve) を用いて, HBSCの質問紙法 で分類された 2 值（active, inactive）に対するMPA， VPA，MVPAの各時間の予測能を比較検討した，AUC は, 0.5 から 1.0 の值を取り, 值が大きいほど予測能が高い， 従属変数は, HBSCの 2 值 (active, inactive) とし, 独 立変数はMPA，VPA，MVPAの各活動時間とした，各 活動時間の ROC 曲線と曲線下の面積 AUC の面積を算出 し, HBSCの質問紙法がいずれの強度の活動時間を最も 予測しているのか，AUCを比較検討した ${ }^{28)}$. AUCの比 較は, 面積の差を標準誤差で除した值の 2 乗が, 自由度 $1 の \chi^{2}$ 分布に準ずることを利用し分析した。

効果量について， $\chi^{2}$ 検定では $2 \times 2$ のクロス集計のた め $\phi$ 係数を用いて評価し，対応のない $\mathrm{t}$ 検定では，Cohen's dを用いて評価した。効果量の小, 中, 大の目安 ${ }^{29}$ として, $\phi$ 係数は, 0.10, 0.30, 0.50 とし, Cohen's d 10.20 , 0.50, 0.80 とした.

なお，分析対象者のうち，一部空白，記入ミ久等がみ られた項目については，その箇所を欠損值とし，すべて を除外せずに分析した。

\section{結果}

基本属性および身体活動の性差 性差について（Table $1)$, 体型の肥満度 $\left(\chi^{2}=4.9, \mathrm{df}=1, \mathrm{P}=0.027, \phi\right.$ 倸数 $\left.=0.11\right)$, HBSCによる active, inactive $\left(\chi^{2}=52.6, \mathrm{df}=1, \mathrm{P}<0.001\right.$, $\phi$ 係数 $=0.32)$, 活動量計によるガイドライン充足，非充 足 $\left(\chi^{2}=118.3, \mathrm{df}=1, \mathrm{P}<0.001, \phi\right.$ 係数 $\left.=0.44\right)$ の分布，お よびMPA（ $t=12.7, d f=453, P<0.001$, Cohen's $d=1.05)$, VPA $(t=11.5, d f=393, P<0.001$, Cohen's $d=0.96)$, MVPA（ $t=13.0, d f=437, P<0.001$, Cohen's $d=1.08)$ の 各時間の全てに有意差がみられた。すなわち, 男子は, 女子に比べて, 肥満児が多いが，身体活動を行っていた。 活動量計の装着日数の平均日数㧍よび標準偏差は, 6.1 \pm 1.2 (平日 $4.2 \pm 0.7$ ，休日 $2.0 \pm 0.7$ ） 日間であり，1 日あ

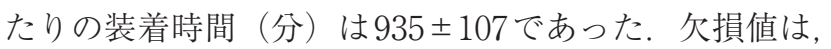
それぞれ性別 1 名, 学年 1 名, 肥満度による体型 203 名, HBSCによる分類103名であった。

\section{質問紙法によって分類された 2 群の強度別活動時間の違} い Table 2 に, 男女別に, HBSCで分類された 2 群（active, inactive）の1日あたりのMPA, VPA, MVPAの各 時間の平均值と分析の結果を示した，男女混合，男子の み，女子のみの集団において，MPA，VPA，MVPAの 各時間全てにおいて有意差がみられ，すなわち，HBSC の質問紙による active 群の児童は, inactive群よりも, MPA，VPA，MVPAの各時間が長かった，効果量Cohen’s dは，MPA，VPA，MVPAの各時間の順に，男女 混合が $0.67 ， 0.70 ， 0.71$ ，男子が $0.60 ， 0.53 ， 0.60$ であり， 女子が $0.30 ， 0.60 ， 0.38$ であった。

活動量計によるMVPA ガイドライン分類とHBSC によ る活動分類の関連 先行研究 ${ }^{4,5)}$ より MVPA 時間が 1 日あたり 60 分以上を基準に分類し，HBSCの質問紙法 による active, inactiveとの一致の度合い，および分布 をTable 3 に示した。一致率の $\phi$ 係数は，男女混合，男 子，女子がそれぞれ $0.25(\mathrm{P}<0.001), 0.17(\mathrm{P}=0.009)$, $0.08 （ \mathrm{P}=0.217 ）$ であり, 男女混合, 男子では有意な 関連がみられた。男子は，感度 82\%（95\%信頼区間 [Confidence Interval, CI]) $=78 \%-86 \%$ ）が，特異度 $34 \%(95 \% \mathrm{CI}=26 \%-41 \%)$ に比べ高く，陽性的中率 が70\%（95\%CI =66\%-73\%）であり，陰性的中率の 50\%（95\%CI =39\%-61\%）に比べ高かった。一方，女 子は，感度 $52 \% （ 95 \% \mathrm{CI}=40 \%-63 \% ）$ と特異度 57\% （95\%CI =55\%-60\%）は，ほぼ変わらず，陰性的中率が 83\%（95\% CI =79\%-87\%）であり，陽性的中率の $23 \%$ （95\%CI = 18\%-28\%）に比べ高かった，男女混合の場 合には，感度 $74 \% （ 95 \% \mathrm{CI}=69 \%-79 \%)$ が，特異度 $51 \%(95 \% \mathrm{CI}=48 \%-54 \%)$ に比心゙高く，陰性的中率が $74 \% （ 95 \% \mathrm{CI}=69 \%-79 \%)$ であり，陽性的中率の $50 \%$ （95\%CI = 47\%-54\%）に比べ高かった。

ROC曲線によるAUC とその比較 Fig. 1には, HBSC の質問紙法で分類された 2 群を従属変数, 各強度別の 
Table 1. Demographic distribution and physical activity and its gender differences

\begin{tabular}{|c|c|c|c|c|}
\hline Variable & $\begin{array}{c}\text { All } \\
(n=606)\end{array}$ & $\begin{array}{c}\text { Boys } \\
(\mathrm{n}=292)\end{array}$ & $\begin{array}{c}\text { Girls } \\
(\mathrm{n}=313)\end{array}$ & \\
\hline \multicolumn{5}{|l|}{ Grade, $\mathrm{n}(\%)$} \\
\hline 4 th & $176(29)$ & $84(29)$ & $92(29)$ & \\
\hline 5 th & $208(34)$ & $105(36)$ & $103(33)$ & \\
\hline 6 th & $221(37)$ & $103(35)$ & $118(38)$ & \\
\hline \multicolumn{5}{|l|}{ Obesity $^{\dagger}, \mathrm{n}(\%)$} \\
\hline $\mathrm{DO}<20$ & $345(86)$ & $154(81)$ & $191(89)$ & \multirow{2}{*}{$*$} \\
\hline $\mathrm{DO} \geqq 20$ & $58(14)$ & 35 (19) & $23(11)$ & \\
\hline \multicolumn{5}{|c|}{ Self-reported PA from the HBSC, $n(\%)$} \\
\hline Active & $296(59)$ & $174(76)$ & $122(44)$ & \multirow{2}{*}{$* * *$} \\
\hline Inactive & $207(41)$ & $54(24)$ & $153(56)$ & \\
\hline \multicolumn{5}{|c|}{$\begin{array}{l}\text { Objective PA using accelerometer, } \\
\text { minutes per day (SD) }\end{array}$} \\
\hline MPA & $53(25)$ & $65(28)$ & $42(16)$ & $* * *$ \\
\hline VPA & $8(7)$ & $11(8)$ & $5(4)$ & $* * *$ \\
\hline MVPA & $61(31)$ & $76(35)$ & $46(18)$ & $* * *$ \\
\hline \multicolumn{5}{|c|}{ the recommended $60-$ min per day of } \\
\hline \multicolumn{5}{|l|}{$\mathrm{MVPA}^{\ddagger}, \mathrm{n}(\%)$} \\
\hline Achievement & $251(41)$ & $187(64)$ & $64(20)$ & \multirow{2}{*}{$* * *$} \\
\hline Non-achievement & 355 (59) & $105(36)$ & $249(80)$ & \\
\hline
\end{tabular}

PA: Physical activity, MPA: Moderate PA, VPA: Vigorous PA, MVPA: Moderate to vigorous PA, HBSC: Health-related behaviour of school aged children. †Obesity is classified from degree of obesity (DO). \$the recommended 60-min per dayof MVPA is based on the guidline ${ }^{4,5)} .{ }^{*} \mathrm{p}<0.05,{ }^{* * *} \mathrm{p}<0.001$

Table 2. Differences in objectively measured daily PA between active and inactive children classified from the HBSC

\begin{tabular}{|c|c|c|c|c|c|c|c|c|c|c|c|c|}
\hline \multirow{3}{*}{$\begin{array}{l}\text { Objective PA using } \\
\text { accelerometer }\end{array}$} & & \multicolumn{8}{|c|}{ Self-reported PA from the HBSC } & & \multirow[b]{3}{*}{ t-value } & \multirow[b]{3}{*}{ Cohen's d } \\
\hline & & \multicolumn{4}{|c|}{ Active } & \multicolumn{4}{|c|}{ Inactive } & & & \\
\hline & & $\mathrm{n}$ & mean & \pm & SD & $\mathrm{n}$ & mean & \pm & SD & & & \\
\hline \multirow[t]{3}{*}{ MPA } & All & 296 & 59.3 & \pm & 27.5 & 207 & 43.2 & \pm & 17.9 & $\mathrm{P}<0.001$ & 7.96 & 0.67 \\
\hline & Boys & 174 & 69.9 & \pm & 29.0 & 54 & 53.8 & \pm & 20.5 & $\mathrm{P}<0.001$ & 4.55 & 0.60 \\
\hline & Girls & 122 & 44.1 & \pm & 15.5 & 153 & 39.4 & \pm & 15.3 & $\mathrm{P}=0.013$ & 2.49 & 0.30 \\
\hline \multirow[t]{3}{*}{ VPA } & All & 296 & 9.6 & \pm & 7.9 & 207 & 4.8 & \pm & 4.6 & $\mathrm{P}<0.001$ & 8.41 & 0.70 \\
\hline & Boys & 174 & 12.1 & \pm & 9.0 & 54 & 7.7 & \pm & 6.7 & $\mathrm{P}<0.001$ & 3.90 & 0.53 \\
\hline & Girls & 122 & 5.9 & \pm & 3.9 & 153 & 3.8 & \pm & 3.0 & $\mathrm{P}<0.001$ & 4.82 & 0.60 \\
\hline \multirow[t]{3}{*}{ MVPA } & All & 296 & 68.9 & \pm & 34.2 & 207 & 47.9 & \pm & 21.4 & $\mathrm{P}<0.001$ & 8.42 & 0.71 \\
\hline & Boys & 174 & 82.1 & \pm & 36.5 & 54 & 61.5 & \pm & 25.2 & $\mathrm{P}<0.001$ & 4.67 & 0.60 \\
\hline & Girls & 122 & 50.0 & \pm & 18.4 & 153 & 43.1 & \pm & 17.7 & $\mathrm{P}=0.002$ & 3.13 & 0.38 \\
\hline
\end{tabular}

PA: Physical activity, MPA: Moderate PA, VPA: Vigorous PA, MVPA: Moderate to vigorous PA, HBSC: Health-related behaviour of school aged children. 
Table 3. Assessment of recommendation related agreement between the self-reported PA and objectively measured PA.

\begin{tabular}{|c|c|c|c|c|c|c|}
\hline \multirow{2}{*}{\multicolumn{2}{|c|}{$\begin{array}{l}\text { Self-reported PA } \\
\text { from the HBSC }\end{array}$}} & \multicolumn{2}{|c|}{$\begin{array}{l}\text { the recommended } 60 \text {-min per day of } \\
\mathrm{MVPA}^{\ddagger}, \mathrm{n}(\%)\end{array}$} & \multirow[t]{3}{*}{$\varphi$ coefficient } & \multirow[t]{2}{*}{ sensitivity } & \multirow[t]{2}{*}{ specificity } \\
\hline & & Achievement & Non-achievement & & & \\
\hline \multirow[t]{3}{*}{ All } & Active & $149(50)$ & $147(50)$ & & & \\
\hline & Inactive & $53(26)$ & $154(74)$ & $0.25 * * *$ & $74 \%$ & $51 \%$ \\
\hline & Total & $202(40)$ & $301(60)$ & & & \\
\hline \multirow[t]{3}{*}{ Boys } & Active & $121(70)$ & $53(30)$ & & & \\
\hline & Inactive & $27(50)$ & $27(50)$ & $0.17 * *$ & $82 \%$ & $34 \%$ \\
\hline & Total & $148(65)$ & $80(35)$ & & & \\
\hline \multirow[t]{3}{*}{ Girls } & Active & $28(23)$ & $94(77)$ & & & \\
\hline & Inactive & $26(17)$ & $127(83)$ & 0.08 & $52 \%$ & $57 \%$ \\
\hline & Total & $54(20)$ & $221(80)$ & & & \\
\hline
\end{tabular}

PA: Physical activity, MVPA: Moderate to vigorous PA, HBSC: Health-related behaviour of school aged children. $\$$ the recommended 60 -min per dayof MVPA is based on the guidline ${ }^{4,5)} \cdot{ }^{*} \mathrm{p}<0.05,{ }^{* * *} \mathrm{p}<0.001$

活動時間を独立変数とした ROC 曲線と AUCを示した， AUCを比較すると, 男女混合ではVPAの予測能が, MPA，MVPAに比べ有意に最も高い值を示した（VPA vs MPA, $\chi^{2}=6.3, \mathrm{df}=1, \mathrm{P}=0.012$; VPA vs MVPA, $\left.\chi^{2}=4.6, \mathrm{df}=1, \mathrm{P}=0.032\right)$. 女子においても, VPAにおけ る予測能が高く, HBSC の質問紙による分類との関連が 最も高かった（VPA vs MPA, $\chi^{2}=8.5, \mathrm{df}=1, \mathrm{P}=0.003$; VPA vs MVPA, $\left.\chi^{2}=6.8, \mathrm{df}=1, \mathrm{P}=0.009\right)$. 一方, 男子で は有意差がみられなかった。

\section{考察}

活動量計で算出された活動時間を基準とし，HBSCの 質問紙法との関連を検討した。その結果，一致率の程度 を示す $\phi$ 係数では, 男女混合, 男子, 女子が, $0.25,0.17$, 0.08であり, 男女混合, 男子では, 有意な関連がみられた。 ただし，有意ではあるが，一致率が高いとは言い難かっ た。また，HBSCの質問紙法によって分類されたactive， inactive 群には, 男女混合, 男子, 女子において, 一日あ たりのMPA，VPA，MVPAの各時間に差がみられた。

活動量計のMVPA 時間を基準とし，男女別に，質問紙 の身体活動評価との関連を検討した先行研究がいくつか みられる。例えば，我が国では，Okuda et al. ${ }^{10)}$ が小学 5 年生を対象に男女別に検討しているが，男女とも，有 意な相関がないと報告していた。一方，国外では，Janz et $\mathrm{al}^{30)}$ の報告がみられ，1 軸活動量計を基準に，質問紙 PAQ-C (Physical Activity Questionnaire for Children) との関連を男女別に検討し，スピアマンの順位相関にお いて，男子（N=216名）が 0.38 ，女子 $(\mathrm{N}=233)$ が 0.24 と報告しており，男女とも，有意ではあるが低い相関が
みられ，男子が女子に比べ高い相関を示していた，最 近では, Benítez-Porres et al. ${ }^{31)}$ が，スペインの男女混 合の小学生を対象（N=83）とし， 3 軸活動量計による MVPA 時間を基準に, PAQ-Cとの関連を検討しており, 男女混合の対象児童に扔いて，スピアマンの順位相関の 值が 0.25 と低い相関（P<0.05）を示していた。これら先 行研究の質問紙法の特性と比べ, 本研究の結果は, 確か に活動量計の種類に違いがあり，また，HBSCの質問紙 の值が量的ではなく，2 群に分類する質的な值との比較 ではあるものの，男女混合，男子では，同等程度の一致 率の関連を示し，さらには，男子の方が女子に比べ精度

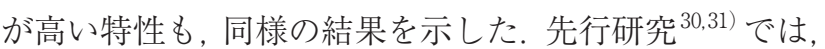
質問紙法の一致の度合いが十分とは言い難く，さらに精 度を高めることが課題として述べられており, 本研究の HBSCによる質問紙においても, 関連の度合いが高いと は言えず，課題が残された。

本研究の男子の $\phi$ 係数が高くなかった要因には, HBSCの質問紙が，MVPA 時間を過大評価していると考 えられる。過大評価は，偽陽性（active, かつ, ガイドラ イン非充足）の分布にみられ，男子の偽陽性は53名であ り，この人数は，ガイドライン非充足の $66 \%$ （80名中 53名）に相当した。つまり，活動量計では，ガイドラ イン非充足に分類される男子が，HBSCの質問紙では， activeに分類された。 ガイドライン非充足であるが，active と過大評価した男子の多さが， $\phi$ 係数に影響してい ると考えられる。

過大評価していたことと関連し, 男子の特異度は, 34\%と低い割合であった，ただし，その一方で，感度は $82 \%$ と特異度に比べ高い割合を示した，感度が高かった 


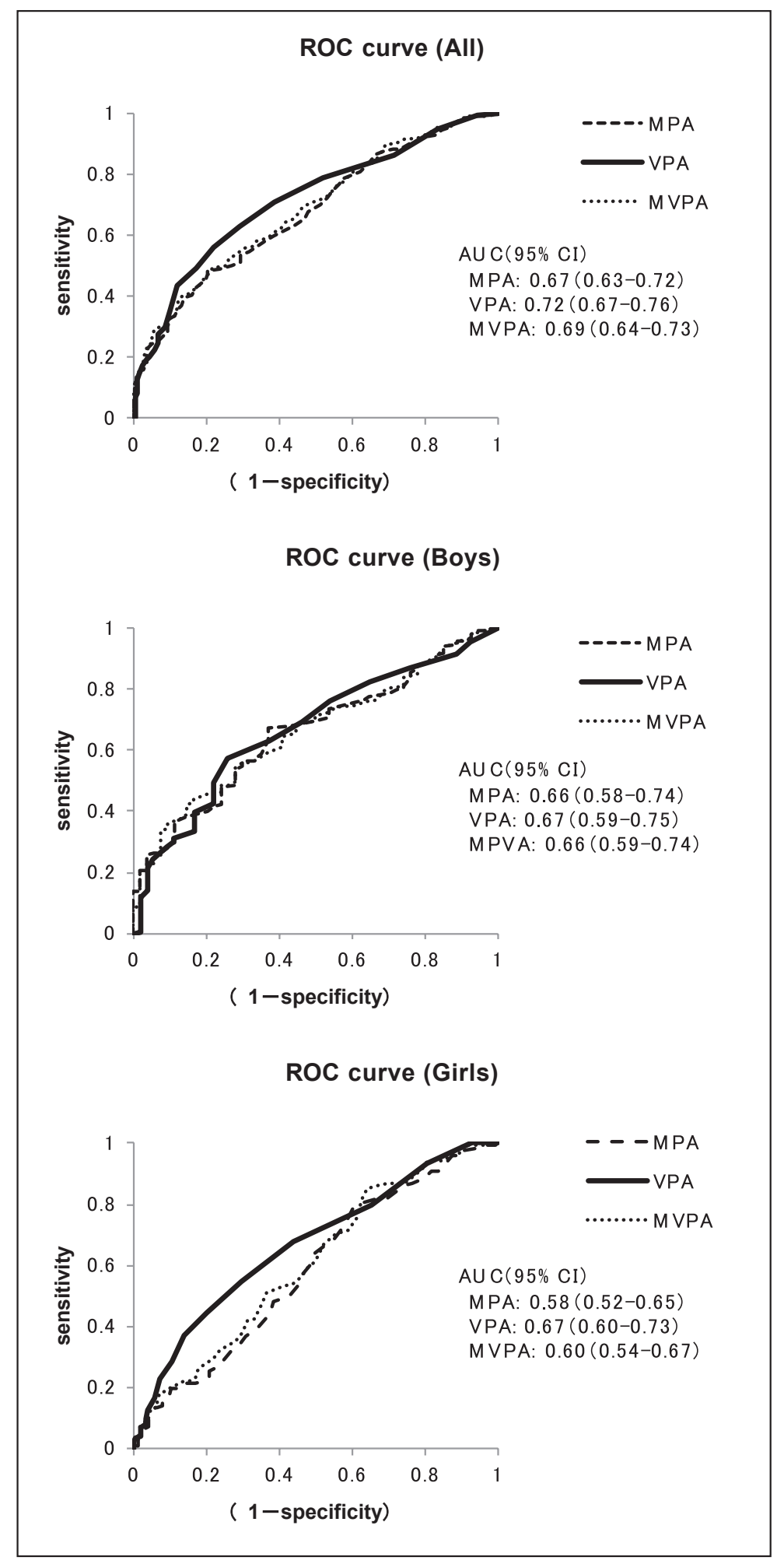

Fig. 1 Comparison with area under the curve (AUC) of receiver operating characteristic (ROC) analysis MPA: moderate physical activity, VPA: vigorous PA, MVPA: moderate and vigorous PA.

ことは，HBSCの質問紙による評価が，活動量計による ガイドライン充足の男子に対し，真にガイドライン充足 となる児童が多く含まれることを示し，その反面，偽陰 性（inactive, かつ, ガイドライン充足）が少ないことも 示している.すわなち, 本研究の調査法は, ガイドライ
ン充足の男子を拾得することに優れているため，拾得さ れなかったinactiveの男子が，ガイドライン非充足であ る確率が高いことを示している。したがって, HBSCの 調査紙による評価は, 男子では, 感度 $(82 \%)$ が特異度 （34％）に比べ高く，ガイドライン非充足を見分けるこ 
とに優れていると考えられた

女子では，有意ではない低い一致率であり，HBSCの 質問紙による評価は，ガイドライン充足，非充足との関 連の度合いが高いとは言い難かった，感度，特異度につ いても, 感度が $52 \%$, 特異度が $57 \%$ と, わずかに特異度 の割合が 5 ポイント高いものの, 男子ほどの違いはみら れなかった。 感度, 特異度の割合と関連し, 女子では, 偽陽性（active, かつ, ガイドライン非充足）が43\%（221 名中 94 名), 偽㓌性（inactive, かつ, ガイドライン充足） が48\%（54名中26名）と同程度の割合を示していた.

感度, 特異度について, 男女による違いがみられた。 男子では, 感度 $82 \%$, 特異度 $34 \%$ と感度が高く, 女子で は感度 $52 \%$, 特異度 $57 \%$ とわずかに特異度が高かった。 この值について，我が国の児童を対象とし，比較できる 研究はみあたらず，今後の研究によってその性能を比較 することが必要であるが, 最近の国外の研究 ${ }^{32}$ において は，質問紙法 PCAE $+{ }^{33)}$ の精度を活動量計（ActiGraph） と比較し, 男女混合の集団に対し, 感度 $53.6 \%$, 特異度 $62.7 \%$ を示していた. PACE ${ }^{33}$ は, 過去 7 日間, および 典型的な 1 週間における 60 分以上の活動的な日数を問い (回答の選択肢は 0 から 7 日間の 8 件法), その回答から ガイドライン充足, 非充足に対象者を分類する調查法で ある. 対象者は, 本研究とほぼ同年代の小学生 87 名 (11.4 土0.4歳, 女子 $67.8 \%$ ）であった。この研究に扔ける感度, 特異度による精度を本研究の結果と比較すると, 本研究 の男子では, 感度が高い值を示し，女子では，感度，特 異度がほぼ同じ割合の精度であった。先行研究 ${ }^{32}$ では, $59 \%$ から $100 \%$ の感度, 特異度による予測精度を中等度 (moderate) あるいは高い（high）としており，本研究 で利用したHBSCの質問紙においても，ある程度の予測 精度があると考えられた。

偽陽性，あるいは偽陰性と判別される男女児童を少な くし，より精度を高めるためには，質問紙の分類基準を 再考することが, 方法の一つとして考えられる, 本研究 では, 先行研究 ${ }^{17)}$ を参考に, 授業外の運動の頻度が「週 に $2 \sim 3$ 回」以上, かつ時間が「週に約 1 時間」以上と 回答した児童を activeとし，それ以外をinactiveとした。 したがって，ガイドライン充足，非充足を評価するため の質問紙とは別様である, 本研究では, 比較が可能なこ とを鑑み, 先行研究 ${ }^{17)}$ と同じ方法を用いており, 従来の 分類方法に扔いて, 活動量計によるガイドラインとの関 連を検討した. しかしながら, 先行研究 ${ }^{17)}$ の分類では, 活動量計によるガイドライン充足, 非充足に対し, 偽陽 性，あるいは女子では偽陰性も比較的多くなることが本 研究により示された，さらに精度を高めるためには, 新 たに頻度，時間による質問項目の組み合わせ，または， いずれかの項目のみによるガイドライン充足, 非充足と の関連を検討していくことも有用であると考えられた.
全体, 男子, 女子の 1 日あたり MPA, VPA, MVPA の各時間において，HBSCによる active群の児童が, inactive群と比べ，全て有意に高い值を示した。したがっ て, HBSCの質問紙法は, 男女児童において, VPA, MPA，MVPAの各時間に差がある集団を分類すること には適していると考えられた，差の大きさを示す効果量 Cohen'dの目安として, 小さな効果量, 中くらいの効果量, 大きな効果量は，それぞれ順に $0.2 ， 0.5,0.8$ と言われて おり ${ }^{29)}$ ，この基準に照らし合わせると，男女混合，男 子の差は, 全て中程度以上の効果量（0.53から 0.71）を 示した。一方，女子に扔いては，VPAの効果量が 0.60 であったが, MPA，MVPAの効果量は0.30，0.38 と比 較的小さい効果量であった。すなわち, 男子に抏いて は, HBSCの質問紙法による active群は, inactive群に 比へ，中等度以上強度の活動時間の差は大きく，女子で は，VPA 時間において差が大きい，という特徵が考え られた，女子のVPA時間については，ROC曲線による AUCが，MPA時間，MVPA時間よりも有意に高い值を 示し, 関連が強いことが考えられた。このことは, 女子 の HBSC の質問紙による評価は，特にVPAの差がある 集団を判別することに適していると考えられた。

ROC曲線に执いて，女子のVPA時間に対し，AUCが 高い值を示したのは，HBSCの質問文のワーディングに よる影響が考えられる. 本研究では, 先行研究 ${ }^{17)}$ の項目 を利用し、「運動・スポーツ活動」に対する回答を得た。 運動・スポーツ活動は, 比較的強度の高い活動に分類さ れ，VPAに相当することが多い，HBSCの質問紙法を用 いて，ガイドラインに沿う分類をするためには，日常生 活での活動も含め, 中等度強度の身体活動に対する小学 生の理解を促進させる調査法への発展が, さらに必要で あると考えられた。このことは，女子のVPAに限らず, ガイドラインに対し高い一致率ではなかったことから も, 男女共通の課題である, 理解の促進については, 例 えば, 先行研究 ${ }^{14)}$ では, ビデオを見ながら回答する方法 に扔いて精度が高かったことが報告されている，近年, ニューメディアの発展が著しく, それらメディアによる 映像，あるいは画像を用いた調査法のキャリブレーショ ンを検討した研究もみられる ${ }^{34)}$.

本研究には，いくつかの限界がある.1つは, 活動量計 について, 活動量計の軸, 装着期間, エポック長によって, MVPA 時間は異なる可能性がある ${ }^{12)}$. 本研究では, 3 軸 活動量計を 10 秒エポックに設定し, 少なくとも平日 3 日 間, 休日 1 日間の計 4 日間, 600 分以上装着した日にちの データを分析した．この基準は，先行研究23)を参考に設 定しているが,これまでの研究では, 60秒エポックの設 定で採取したデー夕を分析したものが多く ${ }^{12)}$ ，エポック 長が異なる活動量計を用いた研究との比較には限界があ る.ただし, 近年では, 短いエポックの方が, 子どもの活 
動を評価するには好ましいことが言われており ${ }^{9,12)}$ ，本 研究の 10 秒エポックによる評価は, 子どもの身体活動 を推定するのに適しているものと考えられる，2つ目に, 4 年生以上の児童を対象としているため, 質問紙による 評価が，低学年の児童に適しているかは不明である，低 学年の児童では, 自分自身で回答が難しいことが考えら れ，低学年の児童が自ら答える質問紙法を開発し，ある いは保護者, 教員など身近な大人が答える方法において も, 関連を検討する必要がある. 3 つ目に, 特定の地方 の小学生のみを対象としており, 気候等の違いが身体活 動に影響することが考えられ，他地域における小学生を 対象に，関連を検討することも課題である，最後に，質

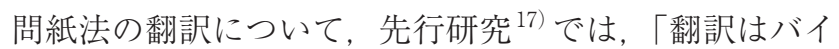
リンガルを含む研究チーム」によって行われたことが記 載されていたが, 具体的な翻訳の手順については記載さ れていない. 本研究では, 原盤から逆翻訳を行って拐ら ず, 先行研究の項目を用いており, 例えば, 異文化によ る尺度との諧調性と関連することも考えられる ${ }^{35)}$. 作成 されてから時間も経過しており, 新たに翻訳するなどし, 性能を高める試みも今後の課題である.

\section{結 論}

本研究の結果より, HBSC の質問紙法は, 小学 4 年生 以上を対象に用いた場合，男女混合，男子では，感度が 特異度より高く, ガイドラインを満たさない児童を見分 けることに優れており, 一方, 女子では特異度が感度よ りもわずかに高かった，男女混合，男子においては，低 い值であるが有意な一致率が認められた，女子では，有 意な一致率を示さず, VPAの予測能が高かった，HBSC の質問紙法で分類されたactive 群と inactive 群には, 男 女混合，男子，女子のすべてに扔いて，MPA，VPA， MVPAの各活動時間に有意差がみられ, active群がinactive群に比べ有意に高かった。

以上より, HBSCの質問紙法による評価は, 男女混合, あるいは男女によって, 感度, 特異度による特性の違い を考慮した上で, 身体活動のガイドライン充足・非充足 に対する予測が, ある程度可能であり, 強度別活動 (MPA, VPA，MVPA）時間に差がある集団を分類する一つの ッールとして役立つと考えられた。ただし，偽陽性の男 女児童, 偽陰性の女子がみられ, ガイドライン充足・非 充足のスクリーニングとしては今後さらに改善の必要性 があった。

利益相反自己申告：申告すべきものはなし

\section{謝 辞}

本研究は, JSPS科研費 (17K01791, 26750323, 23700810, 24680065), 東北学院大学学長研究助成金の助成を一部受け て行われた。

\section{引用文献}

1) Janssen I. Physical activity guidelines for children and youth. Appl Physiol Nutr Metab 32: S109-S121, 2007. doi: 10.1139/H07-109.

2) Janssen I, Leblanc AG. Systematic review of the health benefits of physical activity and fitness in school-aged children and youth. Int J Behav Nutr Phys Act 7: 40, 2010. doi: 10.1186/1479-5868-7-40.

3) Physical Activity Guidelines Advisory Committee. Physical activity guidelines advisory committee report, 2008. Washington, DC: US Department of Health and Human Services, 2008. www.health.gov/paguidelines/ reports/pdf/committeeReport.pdf.

4) World Health Organization. Global recommendations on physical activity for health. Geneva: 60, 2010. doi: 10.1080/11026480410034349.

5）竹中晃二.アクティブ・チャイルド $60 \mathrm{~min}$. -子どもの 身体活動ガイドライン, サンライフ企画, 東京, 2010.

6）笹井浩行, 引原有輝, 岡嵭勘造, 中田由夫, 大河原一憲 : 加速度計による活動量評価と身体活動増進介入一の活 用, 運動疫学研究, 17: 6-18, 2015.

7) Hikihara Y, Tanaka C, Oshima Y, Ohkawara K, Ishikawa-Takata K, Tanaka S. Prediction models discriminating between nonlocomotive and locomotive activities in children using a triaxial accelerometer with a gravity-removal physical activity classification algorithm. PLOS ONE 9: e94940, 2014. doi: 10.1371/journal. pone.0094940.

8）内藤義彦：日常生活に打ける身体活動量の評価：質 問紙による身体活動量評価法, 運動疫学研究, 3: 7-17, 2001.

9）田中千晶, 田中茂穂：身体活動評価からみた発育発達研 究の課題, 子どもと発育発達, 14: 118-128, 2016.

10) Okuda M, Yoshitake N, Tanaka S, Kunitsugu I, Tan N, Uechi H, Sasaki S, Hobara T. Validity and reliability of physical activity questionnaire for Japanese students. Pediatr Int 53: 956-963, 2011. doi: 10.1111/j.1442200X.2011.03434.x.

11) Chen $X$, Sekine M, Hamanishi S, Wang H, Gaina A, Yamagami T, Kagamimori S. Validation of a self-reported physical activity questionnaire for schoolchildren. $J$ Epidemiol 13: 278-287, 2003. doi: 10.2188/jea.13.278.

12) Chinapaw MJ, Mokkink LB, van Poppel MN, van Mechelen W, Terwee CB. Physical activity questionnaires for youth: a systematic review of measurement properties. Sports Med 40: 539-563, 2010. doi: 10.2165/11530770-000000000-00000.

13) Harro M. Validation of a questionnaire to assess physical activity of children ages 4-8 years. Res $Q$ Exerc Sport 68: 259-268, 1997.

14) Tremblay MS, Inman JW, Willms JD. Preliminary evaluation of a video questionnaire to assess activity levels of children. Med Sci Sports Exerc 33: 2139-2144, 2001.

15) Sallis JF, Buono MJ, Roby JJ, Carlson D, Nelson JA. The Caltrac accelerometer as a physical activity mon- 
itor for school-age children. Med Sci Sports Exerc 22: 698-703, 1990.

16) Booth ML, Okely AD, Chey T, Bauman A. The reliability and validity of the physical activity questions in the WHO health behaviour in schoolchildren (HBSC) survey: a population study. Br J Sports Med 35: 263267, 2001.

17）高倉 実, 小林 稔, 宮城政也, 小橋川久光, 加藤種一：児 童における身体活動質問項目の信頼性と妥当性：WHO Health Behaviour in School-aged Children Survey 日本 語版の場合, 琉球大学教育学部紀要, 69: 199-205, 2006.

18）山崎公恵, 松岡尚史, 川野辺重之, 藤田幸子, 村田光範： 1990 年版性別年齢別身長別体重の検討, 日本小児科学会 杂隹誌, 98: 96-102, 1994.

19）日本肥満学会編. I 子どもの肥満症の正しい理解, 肥 満をどのように判定・評価するか, 体重の増加の判定, 小児の肥満症マニュアル (第 1 版), 医歯薬出版, $2-11$, 2008.

20) Ohkawara K, Oshima $Y$, Hikihara $Y$, IshikawaTakata K, Tabata I, Tanaka S. Real-time estimation of daily physical activity intensity by a triaxial accelerometer and a gravity-removal classification algorithm. Br J Nutr 105: 1681-1691, 2011. doi: 10.1017/ S0007114510005441.

21) Park J, Ishikawa-Takata K, Tanaka S, Hikihara Y, Ohkawara K, Watanabe S, Miyachi M, Morita A, Aiba N, Tabata I. Relation of body composition to daily physical activity in free-living Japanese adult women. Br J Nutr 106: 1117-1127, 2011. doi: 10.1017/ S0007114511001358.

22) Tripette J, Ando T, Murakami H, Yamamoto K, Ohkawara K, Tanaka S, Miyachi M. Evaluation of active video games intensity: comparison between accelerometer-based predictions and indirect calorimetric measurements. Technol Health Care 22: 199-208, 2014. doi: 10.3233/THC-140817.

23) Cain KL, Sallis JF, Conway TL, Van Dyck D, Calhoon L. Using accelerometers in youth physical activity studies: a review of methods. J Phys Act Health 10: 437450, 2013

24) Trost SG, Pate RR, Sallis JF, Freedson PS, Taylor WC, Dowda M, Sirard J. Age and gender differences in objectively measured physical activity in youth. Med Sci Sports Exerc 34: 350-355, 2002.

25) Ishii K, Shibata A, Adachi M, Nonoue K, Oka K. Gender and grade differences in objectively measured physical activity and sedentary behavior patterns among Japanese children and adolescents: a cross- sectional study. BMC Public Health 18: 1254, 2015. doi: 10.1186/s12889-015-2607-3.

26) Van Hecke L, Loyen A, Verloigne M, van der Ploeg HP, Lakerveld J, Brug J, De Bourdeaudhuij I, Ekelund U, Donnelly A, Hendriksen I, Deforche B. Variation in population levels of physical activity in European children and adolescents according to cross-European studies: a systematic literature review within DEDIPAC. Int J Behav Nutr Phys Act 13: 70, 2016. doi: 10.1186/s12966-016-0396-4.

27）新谷 歩. 感度 · 特異度, 今日から使える医療統計（第 1 版), 医学書院, 東京, 135-159, 2016.

28) DeLong ER, DeLong DM, Clarke-Pearson DL. Comparing the areas under two or more correlated receiver operating characteristic curves: a nonparametric approach. Biometrics 44: 837-845, 1988.

29) Cohen J. A power primer. Psychol Bull 112: 155-159, 1992.

30) Janz KF, Medema-Johnson HC, Letuchy EM, Burns TL, Gilmore JM, Torner JC, Willing M, Levy SM. Subjective and objective measures of physical activity in relationship to bone mineral content during late childhood: the Iowa Bone Development Study. Br J Sports Med 42: 658-663, 2008. doi: 10.1136/bjsm.2008.047779.

31) Benítez-Porres J, López-Fernández I, Raya JF, Álvarez Carnero S, Alvero-Cruz JR, Álvarez Carnero E. Reliability and Validity of the PAQ-C Questionnaire to Assess Physical Activity in Children. J Sch Health 86: 677-685, 2016. doi: 10.1111/josh.12418.

32) Murphy MH, Rowe DA, Belton S, Woods CB. Validity of a two-item physical activity questionnaire for assessing attainment of physical activity guidelines in youth. BMC Public Health 15: 1080, 2015. doi: 10.1186/ s12889-015-2418-6.

33) Prochaska JJ, Sallis JF, Long B. A physical activity screening measure for use with adolescents in primary care. Arch Pediatr Adolesc Med 155: 554-559, 2001.

34) Web-based assessments of physical activity in youth: considerations for design and scale calibration. $J$ Med Internet Res 16: e269, 2014. doi: 10.2196/jmir.3626.

35) Wild D, Grove A, Martin M, Eremenco S, McElroy S, Verjee-Lorenz A, Erikson P. Principles of Good Practice for the Translation and Cultural Adaptation Process for Patient-Reported Outcomes (PRO) Measures: report of the ISPOR Task Force for Translation and Cultural Adaptation. Value Health 8: 94-104, 2005. doi: 10.1111/j.1524-4733.2005.04054.x. 